\title{
DNA Repair Genes XRCC1, XRCC3, XPD, and OGG1 Polymorphisms among the Central Region Population of Saudi Arabia
}

\author{
Mohammad Alanazia, Akbar Ali Khan Pathana, Sana Abdulla Ajajb, Wajahatullah Khana, Jilani P. Shaik, Nada Al \\ Tassan', Narasimha Reddy Parine ${ }^{\text {a* }}$
}

a Genome Research Chair, Department of Biochemistry, College of Science, King Saud University, Riyadh, Saudi Arabia.

${ }^{b}$ Family Medicine Department, College of Medicine, King Saud University, Riyadh, Saudi Arabia.

c Department of Genetics, King Faisal Specialist Hospital and Research Centre, Riyadh, Saudi Arabia.

\begin{abstract}
DNA repair is one of the central defense mechanisms against mutagenic exposures. Inherited SNPs of DNA repair genes may contribute to variations in DNA repair capacity and susceptibility to cancer. Due to the presence of these variants, inter-individual and ethnic differences in DNA repair capacity have been established in various populations. Saudi Arabia harbors enormous genetic and cultural diversity. In the present study we aimed to determine the genotype and allele frequencies of XRCC1 Arg399Gln (rs25487), XRCC3 Thr241Met (rs861539), XPD Lys751Gln (rs13181), and OGG1 Ser326Cys (rs1052133) gene polymorphisms in 386 healthy individuals residing in the central region of Saudi Arabia and compare them with HapMap and other populations. The genotype and allele frequencies of the four DNA repair gene loci in central Saudi population showed a distinctive pattern. Furthermore, comparison of polymorphisms in these genes with other populations also showed a unique pattern for the central Saudi population. To the best of our knowledge, this is the first report that deals with these DNA repair gene polymorphisms among the central Saudi population.
\end{abstract}

Key words: DNA Repair genes; polymorphism; Saudi population; XRCC1; XRCC3; OGG1; XPD

\section{INTRODUCTION}

Genetic variation plays a critical role in most diseases, however gene-environment interactions may also be important in various ways, either by risk due to individual or population genotypes or by differential gene risk based on exposure (Iannuzzi et al., 2002; Gangwar et al., 2009). Exposure of cells to physical and chemical agents, including ionizing radiation and other toxic chemicals, results in DNA damage, potentially causing loss of genetic integrity and elevated cancer risk. The integrity of the damaged DNA is typically restored by the action of certain DNA repair enzymes (Charames and Bapat, 2003; Vettriselvi et al., 2007). Hence the integrity, preservation and stability of the human genome depend on the DNA repair mechanism, which is essential to cellular and physiological processes. Any harmful mutations in the DNA repair mechanism genes can lead to genomic instability, eventually causing cancer and ageing. Genetic polymorphisms in DNA repair genes may influence inter-individual variation in DNA repair capacity by altering the functional properties of DNA repair enzymes and thus modulate susceptibility to cancer (Lunn et al., 1999).

The X-ray repair cross-complementing group 1 (XRCC1, 19q13.2) gene synthesizes a protein implicated in singlestrand break (SSB) repair including base excision repair (BER) of affected bases as a result of endogenous and exogenous oxidants (Skjelbred et al., 2006). It interacts with human polynucleotide kinase enzyme as well as with DNA polymerase-b, poly (ADP-ribose) polymerase and DNA ligase III a (Pramanik et al., 2011). Several mutations in XRCC1 have been reported to disrupt the protein function by altering binding sites or the catalytic domain of the protein (Caldecott, 2003). The Arg399Gln polymorphism is an arginine to glutamine substitution at codon 399 of exon 10 (C > T, rs25487) and is located in the conserved residue of the poly (ADPribose) polymerase-binding domain of XRCC1 (Pramanik et al., 2011). The association between XRCC1 and various types of cancers such as lung cancer (Ratnasinghe et al., 2001), breast cancer (Moullan et al., 2003) and head and neck cancer (Sturgis et al., 1999) has previously been studied.

The X-ray repair cross-complementing group 3 (XRCC3) gene is a member of the RecA/Rad51-related protein complex responsible for the homologous recombinational repair (HRR) of double-strand DNA and is necessary for the stability of the genome (Cui et al., 1999; Griffin et al., 2000; Brenneman et al., 2000). The $\mathrm{C}>\mathrm{T}$ transition is the most often occurring polymorphism in the XRCC3 gene at codon 241, causing an amino acid change (Thr to Met) (Pramanik et al., 2011). Carriers of the Met allele showed a relatively high DNA adduct level in lymphocytes, which could be associated with reduced DNA repair capacity (Matullo et al., 2001a; Matullo et al., 2001b). An association between the XRCC3 241Met allele and cancer has been observed in various studies, including investigations of bladder cancer (Matullo et al., 2001a), breast cancer (Kuschel et al., 2002), colorectal cancer (Krupa et al., 2011), lung cancer (Improta et al., 2008) and astrocytomas and glioblastomas (Custodio et al., 2012).

The xeroderma pigmentosum complementation group D (XPD) gene encodes an ATP-dependent DNA helicase located $1.8 \mathrm{Mb}$ downstream of XRCC1 on chromosome 19q13.3. XPD; it is a vital component of the Transcription Factor IIH that is involved in nucleotide excision repair (NER) of UV-induced damage and removal of bulky DNA adducts (Chen and Kadlubar, 2003). The Lys751Gln ( $>$ G, rs13181) polymorphism at codon 751 of exon 23 causes a non-synonymous substitution 
that changes lysine to glutamine. The Lys751Gln polymorphism in the XPD gene is critical; it alters the conformation of the respective amino acid in the important domain of the protein that plays a role in protein interaction (Benhamou and Sarasin, 2002). The $751 \mathrm{Gln}$ variant has been implicated in several casecontrol association studies, i.e. esophageal cancer (Yuan et al., 2011), lung cancer (Zhan et al., 2010), breast cancer (Samson et al., 2011), and melanoma patients (Kertat et al., 2008).

Human 8-oxoguanine glycosylase 1 (hOGG1) is synthesized by the 8-oxoguanine DNA glycosylase (OGG1) gene, which is located at chromosome 3p26.2, a region that often shows loss of heterozygosity in several human cancers (Kohno et al., 2006; Shinmura and Yokota, 2001). The OGG1 gene is involved in the repair of 8-oxoguanine (8-oxoG), a highly mutagenic guanine base lesion formed due to the action of reactive oxygen species (ROS) on DNA. The OGG1 gene belongs to the base excision repair pathway and has a DNA glycosylase/AP-lyase activity, catalyzing the excision of 8-oxoG. Several polymorphisms in the OGG1 gene have previously been reported; however, most of the studies have focused on the Ser326Cys polymorphism causing a substitution of serine to cysteine at codon 326 of exon 7 (C > G, rs1052133). The OGG1 326Cys allele is associated with a higher risk of developing many different types of cancers, including lung (Kohno et al., 2006) and orolaryngeal cancers (Elahi et al., 2002).

In Saudi Arabia many tribes have settled in different regions for decades; these tribes can be identified by family names. The families were grouped according to the province of their origin (El-Hazmi et al., 1995). Most of these tribes have social and traditional restrictions (El-Hazmi et al., 1995). We collected the samples from the families which reside only in central region.

The present study was performed to investigate the allele and genotype frequencies of four non-synonymous SNPs, rs25487 (XRCC1), rs861539 (XRCC3), rs13181 (XPD), and rs1052133 (OGG1) in the central region population of Saudi Arabia and compare them with HapMap and other populations.

\section{MATERIAL AND METHODS}

\section{Study population}

The study involved a total of 386 subjects (194 males and 192 females) with ages ranging from 25-70 years from central region of Saudi Arabia. Unrelated healthy subjects from the general population belonging to the same geographical region with similar ethnicity were used for this study. The King Khalid University Hospital ethical committee approved the study and informed consent was obtained from the participating volunteers.

\section{DNA extraction}

Approximately $3 \mathrm{ml}$ of blood were collected in sterile tubes containing ethylenediaminetetracetic acid (EDTA) from all subjects enrolled in the study. Genomic DNA was isolated from blood samples using the QIAmp kit (QIAmp DNA blood Mini Kit, Qiagen, Valencia, CA) following the manufacturer's instructions. After extraction and purification, the DNA was quantified on a NanoDrop 8000 to determine the concentration, and its purity was examined using standard A260/A280 and A260 / A230 ratios (NanoDrop 8000) (Sambrook et al., 1989).
Genotyping

SNPs in four DNA repair genes XRCC1 (Arg399Gln, rs25487), XRCC3 (Thr241Met, rs861539), XPD (Lys751Gln, rs13181), and OGG1 (Ser326Cys, rs1052133) were genotyped using TaqMan allelic discrimination assay (Livak, 1999). For each sample, 5 ng DNA per reaction was used with $2.5 \mu \mathrm{L}$ of $2 \mathrm{X}$ Universal Master Mix and $200 \mathrm{nM}$ primers (Applied Biosystems, Foster City, CA, USA). All genotypes were determined by endpoint reading on an ABI 7500 (Applied Biosystems, Foster City, CA, USA). Primers and probe mix were purchased directly through the assays-on-demand service of Applied Biosystems. Five percent of the samples were randomly selected and subjected to repeat analysis as a quality control measure for verification of genotyping procedures.

\section{Statistical analysis}

A Chi square $(\chi 2)$ test was used to compare the observed genotype distributions of the XRCC1, XRCC3, XPD and OGG1 polymorphisms with their expected values. The allele and genotype frequencies of polymorphisms in the central region population of Saudi Arabia (CRS) were compared with some of the populations of the HapMap database (www.hapmap. org), for example, Utah residents with northern and western European ancestry from the CEPH collection (CEU), Han Chinese in Beijing, China (CHB), Yoruba in Ibadan, Nigeria (YRI), Maasai in Kinyawa, Kenya (MKK), and Japanese in Tokyo, Japan (JPT) and some other populations selected from the literature e.g., eastern population of Saudi Arabia (Jeddah) (Harithy and Ghazzawi, 2011), and eastern population of India (EInd) (eastern Indian ethnicity from Calcutta, West Bengal state) (Majumder et al., 2005; Majumder et al., 2007). Pair-wise Chi square $\left(\chi^{2}\right)$ tests were performed between the central region population of Saudi Arabia (CRS) and other populations using the allele frequencies in a $2 \times 2$ contingency table to study if the central region of Saudi population (CRS) shows significant differences compared to other populations. Additionally, Bonferroni's correction was applied for multiple comparisons of the populations.

\section{RESULTS}

The allele and genotype frequencies of rs25487 (Arg399Gln, XRCC1), rs861539 (Thr241Met, XRCC3 gene), rs13181 (Lys751Gln, XPD gene), and rs1052133 (Ser326Cys, OGG1gene) polymorphisms in the CRS population are shown in Table I. The observed genotype frequencies did not show any significant departure from Hardy-Weinberg expectations for all four polymorphic loci that were observed in this study.

Allele and genotype frequencies of XRCC1 Arginine399Glutamine (C > T)

The observed Arg/Arg, Arg/Gln and Gln/Gln genotype frequencies were $0.528,0.37$ and 0.10 , respectively (Table II). The Arg (wild-type) and Gln (variant) allele frequencies were 0.71 and 0.29 , respectively. The variant Gln (variant) allele frequency varied from 0.11 among YRI to 0.37 among CEU. Of all the HapMap populations including CEU, CHB, MKK, YRI and JPT including other EInd and Jeddha populations selected for this study, only YRI, MKK and CEU were found to be significantly different from the CRS population using the Chisquare $(\chi 2)$ test (Table II). 
TABLE I

Distribution of genotypes and allele frequencies in XRCC1, XRCC3, XPD and OGG1 loci in the central Saudi population (CRS)

\begin{tabular}{lccc}
\hline \multicolumn{1}{c}{ Genotype (SNP ID) } & Total subjects (N) & Allele frequency & HWE \\
P-value
\end{tabular}

TABLE II

Allele and genotype frequencies of XRCC1 Arg399Gln in the central Saudi and other populations

\begin{tabular}{|c|c|c|c|c|c|c|c|}
\hline \multirow[b]{2}{*}{ Population } & \multicolumn{3}{|c|}{ Genotype Freq (N) } & \multicolumn{2}{|c|}{ Allele frequency } & \multirow{2}{*}{$\begin{array}{l}\text { Pairwise } \chi^{2} \text { test value between } \\
\text { CRS \& other populations }\end{array}$} & \multirow[b]{2}{*}{ Cp Value } \\
\hline & $\begin{array}{l}\text { Arg/Arg } \\
\text { Freq (N) }\end{array}$ & $\begin{array}{l}\text { Arg/ Gln } \\
\text { Freq (N) }\end{array}$ & $\begin{array}{l}\text { Gln / Gln } \\
\text { Freq (N) }\end{array}$ & $\begin{array}{l}\text { Wild type } \\
\text { Arg }\end{array}$ & $\begin{array}{l}\text { Variant } \\
\text { Gln }\end{array}$ & & \\
\hline CEU (n=224) & $0.38(86)$ & $0.5(112)$ & $0.11(26)$ & 0.63 & 0.37 & 12.22 & 0.0154 \\
\hline $\mathrm{CHB}(\mathrm{n}=83)$ & $0.55(48)$ & $0.38(30)$ & $0.06(4)$ & 0.75 & 0.25 & 2.42 & 1 \\
\hline $\mathrm{JPT}(\mathrm{n}=172)$ & $0.52(90)$ & $0.4(70)$ & $0.07(12)$ & 0.73 & 0.27 & 1.69 & 1 \\
\hline EInd $(n=385)$ & $0.44(170)$ & 0.465 (179) & $0.093(36)$ & 0.67 & 0.33 & 7.23 & 0.18 \\
\hline YRI (n=226) & $0.78(176)$ & $0.22(50)$ & 0 & 0.89 & 0.11 & 47.27 & $3.79 \times 10-10$ \\
\hline MKK $(\mathrm{n}=286)$ & $0.32(92)$ & $0.66(188)$ & $0.021(6)$ & 0.82 & 0.18 & 59.12 & $1.1 \times 10-12$ \\
\hline Jed $(n=65)$ & $0.523(34)$ & $0.38(25)$ & $0.09(6)$ & 0.72 & 0.28 & 0.075 & 1 \\
\hline CRS (n=386) & $0.528(204)$ & $0.37(143)$ & $0.10(39)$ & 0.71 & 0.29 & - & \\
\hline
\end{tabular}

Population descriptions:

CEU-Utah residents with northern and western European ancestry from the CEPH collection.

CHB-Han Chinese in Beijing, China.

JPT-Japanese in Tokyo, Japan.

Elnd-eastern Indian population from Calcutta, India (Majumder et al., 2007).

YRI: Yoruba in Ibadan, Nigeria.

MKK: Masai in Kinyawa, Kenya.

Jed: Saudi population residing in Jeddah region of western Saudi Arabia (Harithy and Ghazzawi et al., 2011)

CRS- Saudi population residing in the Riyadh region of central Saudi Arabia.

$\mathrm{CP}$ - $\mathrm{P}$ values corrected by the Bonferroni correction. 
Allele and genotype frequencies of XRCC3 Threonine241Methionine $(G>A)$

The observed Thr/Thr, Thr/Met and Met/Met genotype frequencies were $0.42,0.42$ and 0.16 , respectively (Table III), whereas the Thr (wild-type) and Met (variant) allele frequencies were 0.79 and 0.21 , respectively. The variant allele frequency varied from $0.07(\mathrm{CHB})$ to 0.43 (CEU). The CRS and $\mathrm{CHB}, \mathrm{JPT}$, EInd, YRI and MKK populations differed significantly based on pair-wise Chi-square $(\chi 2)$ tests (Table III).

Allele and genotype frequencies of XPD Lysine751Glutamine $(T>G)$

The observed Lys/Lys, Lys/Gln and Gln/Gln genotype frequencies were $0.38,0.44$ and 0.18 , respectively (Table IV). The Lys (wild-type) allele frequency was 0.60 , while the Gln (variant) allele frequency was 0.40 . The variant allele frequency varied from 0.076 in JPT to 0.33 in CEU. All the populations differed significantly from the CRS population (Table IV).

Allele and genotype frequencies of OGG1 Ser326Cys (C > G)

The observed Ser/Ser, Ser/Cys and Cys/Cys genotype frequencies were $0.464,0.404$ and 0.132 , respectively (Table V). The serine (wild-type) and cysteine (variant) allele frequencies were 0.666 and 0.334 , respectively. The variant allele frequency varied from 0.144 (YRI) to 0.523 (JPT). There were no allele and genotype frequency data available for the MKK population in the HapMap and EInd among the Indian populations (Table V). Except for CEU, all the other populations were found to be significantly different from the CRS population (Table V).

\section{DISCUSSION}

The aim of this study was to investigate the polymorphisms in healthy Saudi individuals for the four DNA repair genes XRCC1, XRCC3, XPD and OGG1 and to compare their frequencies with other populations. Polymorphisms in genes that are involved in carcinogen metabolism and DNA repair mechanism have been reported to be a source of inter-individual variability in human response to carcinogens. Although several studies have been carried out that deal with the heritable polymorphisms among genes responsible for carcinogen metabolism in recent years, very few reports have been published in relation to DNA repair capacity and development of cancer in different populations (Friedberg et al., 1995; Vettriselvi et al., 2007; Pramanik et al., 2011). Individuals generally differ widely in their capacity to repair damaged DNA as a result of external agents such as exposure to sunlight and tobacco smoke, as well as endogenous oxidation reactions. Hence the present study was performed to determine the genotype distribution of DNA repair genes XRCC1, XRCC3, OGG1 and XPD among the ethnic population living in the central region of Saudi Arabia. The is the first report that deals with the frequency distribution of DNA repair genes XRCC1, XRCC3, OGG1 and XPD in the central region population of Arabian Peninsula.

In the present study XRCC1 Arg399Gln genotype frequencies showed a significant deviation in the CRS compared to the CEU, MKK and YRI populations (Table II). However, similarities were found in the CRS and the CHB, JPT, EInd and Jeddah populations. Jeddah population genotyping data was available only for XRCC1 and no significant difference was observed between the Riyadh and

TABLE III

Allele and genotype frequencies of XRCC3 Thr241Met in the central Saudi and other populations

\begin{tabular}{|c|c|c|c|c|c|c|c|}
\hline \multirow[b]{2}{*}{ Population } & \multicolumn{3}{|c|}{ Genotype Freq (N) } & \multicolumn{2}{|c|}{ Allele frequency } & \multirow{2}{*}{$\begin{array}{l}\text { Pairwise } \chi^{2} \text { test value between } \\
\text { CRS \& other populations }\end{array}$} & \multirow[b]{2}{*}{ Cp Value } \\
\hline & $\begin{array}{l}\text { Thr/ Thr } \\
\text { Freq (N) }\end{array}$ & $\begin{array}{l}\text { Thr / Met } \\
\text { Freq (N) }\end{array}$ & $\begin{array}{l}\text { Met / Met } \\
\text { Freq }(\mathrm{N})\end{array}$ & $\begin{array}{c}\text { Wild type } \\
\text { Thr }\end{array}$ & $\begin{array}{l}\text { Variant } \\
\text { Met }\end{array}$ & & \\
\hline CEU $(n=226)$ & $0.31(70)$ & $0.52(118)$ & $0.17(38)$ & 0.57 & 0.43 & 8.06 & 0.102 \\
\hline $\mathrm{CHB}(\mathrm{n}=82)$ & $0.85(70)$ & $0.15(12)$ & 0 & 0.93 & 0.07 & 52.12 & $2.87 \times 10-11$ \\
\hline JPT (n=172) & $0.79(136)$ & $0.20(34)$ & $0.01(2)$ & 0.89 & 0.11 & 69.93 & $3.91 \times 10-15$ \\
\hline EInd $(n=348)$ & $0.63(220)$ & $0.34(120)$ & $0.03(8)$ & 0.80 & 0.20 & 54.47 & $8.87 \times 10-12$ \\
\hline YRI (n=224) & $0.67(150)$ & $0.321(72)$ & $0.009(2)$ & 0.83 & 0.17 & 51.59 & $3.76 \times 10-11$ \\
\hline MKK $(n=286)$ & $0.64(182)$ & $0.31(90)$ & $0.05(14)$ & 0.79 & 0.21 & 37.62 & $4.06 \times 10-8$ \\
\hline CRS $(n=386)$ & $0.42(163)$ & $0.42(162)$ & $0.16(62)$ & 0.63 & 0.37 & - & \\
\hline
\end{tabular}

Population descriptions:

CEU-Utah residents with northern and western European ancestry from the CEPH collection.

CHB-Han Chinese in Beijing, China.

JPT-Japanese in Tokyo, Japan.

Elnd-eastern Indian population from Calcutta, India (Majumder et al., 2007).

YRI: Yoruba in Ibadan, Nigeria.

MKK: Masai in Kinyawa, Kenya.

Jed: Saudi population residing in Jeddah region of western Saudi Arabia (Harithy and Ghazzawi et al. 2011)

CRS- Saudi population residing in the Riyadh region of central Saudi Arabia.

$\mathrm{CP}$ - $\mathrm{P}$ values corrected by the Bonferroni correction. 
Jeddah populations. This could be due to the fact that the samples drawn from populations from these two regions were composed of individuals who were randomly selected and did not represent any particular ethnic group.

Apart from the XRCC1 locus, allele frequencies and genotype distributions of the SNPs in the XRCC3, XPD and OGG1 loci varied significantly between different populations. Populations CHB, JPT and YRI were significantly different from CRS for the XRCC3, XPD and OGG1 loci, whereas the CRS population differed significantly from YRI for all the DNA repair gene loci. Similarly, the MKK population differed significantly from the CRS for all the DNA repair gene loci except for OGG1, for which HapMap data were not available. The CEU population did not show a significant difference with the CRS population for XRCC3 and OGG1 loci.

The frequency of the variant allele of XRCC1codon 399 observed in the present study (0.29) was very similar to earlier reports from the Jeddah (0.28), CHB (0.25) and JPT (0.27) populations. The XRCC1 399 polymorphism has been reported to be associated with head and neck cancer risk (Alsbeih et al., 2008) in the Saudi population; by contrast Harithy and Ghazzawi, (2011) reported that this loci conferred protection in Saudi colon cancer patients. This may be due to an association with other SNPs. XRCC1 is also reported to be associated

TABLE IV

Allele and genotype frequencies of XPD Lys751Gln in the central Saudi and other populations

\begin{tabular}{|c|c|c|c|c|c|c|c|}
\hline \multirow[b]{2}{*}{ Population } & \multicolumn{3}{|c|}{ Genotype Freq (N) } & \multicolumn{2}{|c|}{ Allele frequency } & \multirow{2}{*}{$\begin{array}{l}\text { Pairwise } \chi^{2} \text { test value between } \\
\text { CRS \& other populations }\end{array}$} & \multirow[b]{2}{*}{ Cp Value } \\
\hline & $\begin{array}{l}\text { Lys/Lys } \\
\text { Freq (N) }\end{array}$ & $\begin{array}{l}\text { Lys /Gln } \\
\text { Freq (N) }\end{array}$ & $\begin{array}{l}\text { Gln /Gln } \\
\text { Freq (N) }\end{array}$ & $\begin{array}{l}\text { Wild type } \\
\text { Lys }\end{array}$ & $\begin{array}{c}\text { Variant } \\
\text { Gln }\end{array}$ & & \\
\hline $\operatorname{CEU}(n=226)$ & $0.4(92)$ & $0.522(118)$ & $0.071(16)$ & 0.668 & 0.332 & 14.9 & 0.003483 \\
\hline $\mathrm{CHB}(\mathrm{n}=82)$ & $0.76(62)$ & $0.24(20)$ & 0 & 0.82 & 0.12 & 41.96 & $4.62 \times 10-9$ \\
\hline $\mathrm{JPT}(\mathrm{n}=172)$ & $0.860(148)$ & $0.128(22)$ & $0.012(2)$ & 0.924 & 0.076 & 110.6 & $5.75 \times 10-24$ \\
\hline EInd (n=388) & 0.49 (190) & $0.407(158)$ & $0.103(40)$ & 0.69 & 0.31 & 13.7 & 0.006349 \\
\hline YRI $(n=226)$ & $0.65(146)$ & $0.34(76)$ & $0.01(4)$ & 0.82 & 0.18 & 55.53 & $5.24 \times 10-12$ \\
\hline $\operatorname{MKK}(\mathrm{n}=286)$ & 0.67 (192) & $0.29(82)$ & $0.04(12)$ & 0.81 & 0.19 & 62.81 & $1.38 \times 10-13$ \\
\hline CRS $(n=386)$ & $0.38(148)$ & $0.44(168)$ & $0.18(70)$ & 0.60 & 0.40 & - & \\
\hline
\end{tabular}

Population descriptions:

CEU-Utah residents with northern and western European ancestry from the CEPH collection.

CHB-Han Chinese in Beijing, China.

JPT-Japanese in Tokyo, Japan.

Elnd-eastern Indian population from Calcutta, India (Majumder et al., 2007)

YRI: Yoruba in Ibadan, Nigeria.

MKK: Masai in Kinyawa, Kenya.

CRS- Saudi population residing in the Riyadh region of central Saudi Arabia.

$\mathrm{CP}$ - $\mathrm{P}$ values corrected by the Bonferroni correction.

TABLE V

Allele and genotype frequencies of OGG1 Ser326Cys in the central Saudi and other populations

\begin{tabular}{|c|c|c|c|c|c|c|c|}
\hline \multirow[b]{2}{*}{ Population } & \multicolumn{3}{|c|}{ Genotype Freq (N) } & \multicolumn{2}{|c|}{ Allele frequency } & \multirow{2}{*}{$\begin{array}{l}\text { Pairwise } \chi^{2} \text { test value between } \\
\text { CRS \& other populations }\end{array}$} & \multirow[b]{2}{*}{ Cp Value } \\
\hline & $\begin{array}{l}\text { Ser / Ser } \\
\text { Freq (N) }\end{array}$ & $\begin{array}{l}\text { Ser / Cys } \\
\text { Freq (N) }\end{array}$ & $\begin{array}{l}\text { Cys / Cys } \\
\text { Freq (N) }\end{array}$ & $\begin{array}{l}\text { Wild type } \\
\text { Ser }\end{array}$ & $\begin{array}{c}\text { Variant } \\
\text { Cys }\end{array}$ & & \\
\hline CEU $(n=116)$ & $0.621(72)$ & $0.310(36)$ & $0.069(8)$ & 0.776 & 0.224 & 9.47 & 0.052 \\
\hline $\mathrm{CHB}(\mathrm{n}=90)$ & $0.244(22)$ & $0.511(46)$ & $0.244(22)$ & 0.5 & 0.5 & 16.28 & 0.0017 \\
\hline $\mathrm{JPT}(\mathrm{n}=88)$ & $0.182(16)$ & $0.59(52)$ & $0.227(20)$ & 0.477 & 0.523 & 23.87 & $3.93 \times 10-5$ \\
\hline YRI (n=118) & $0.746(88)$ & $0.22(26)$ & $0.034(4)$ & 0.856 & 0.144 & 30.01 & $1.82 \times 10-6$ \\
\hline CRS (n=386) & $0.464(179)$ & $0.404(156)$ & $0.132(51)$ & 0.666 & 0.334 & - & \\
\hline
\end{tabular}

Population descriptions:

CEU-Utah residents with northern and western European ancestry from the CEPH collection.

CHB-Han Chinese in Beijing, China.

JPT-Japanese in Tokyo, Japan.

YRI: Yoruba in Ibadan, Nigeria.

CRS- Saudi population residing in the Riyadh region of central Saudi Arabia.

$\mathrm{CP}$ - $\mathrm{P}$ values corrected by the Bonferroni correction. 
with different cancers in the Chinese population, for example, hepatocellular carcinoma (Duan et al., 2012) and esophageal cancer (Zhang et al., 2013). These reports show a similar trend in cancer risk to XRCC1 399 polymorphisms in Saudi, Chinese and Japanese populations. In contrast, the European population did not show an association with XRCC1 399 polymorphism in lung cancer patients (Lopez-Cima et al., 2007) or in bladder patients (Kelsey et al., 2004). Perhaps the XRCC1 399 variant allele (frequency 0.37 ) is conferring protection for lung and bladder cancer in the European population. Up to now there are no reports in the MKK and YRI populations on XRCC1, XRCC3, XPD and OGG1 gene polymorphisms associated with cancer and other diseases.

The frequency of the variant allele of the XRCC 3 codon 241 was less than $21 \%$ in all the tested populations except for the CEU (0.43) and Saudi populations (0.37). The XRCC3 Thr241Met and XPD Lys751Gln polymorphisms showed significant association with breast cancer risk in European, Chinese, Japanese, and Indian populations. The European population did not show an association with XRCC3 Thr241Met and XPD Lys751Gln polymorphism in lung cancer patients (Lopez-Cima et al., 2007) or bladder cancer patients Andrew et al. (2006). Xue et al., (2012) reported that XPD 241Met was more highly associated with gastric cancer in the Asian population than in the European population. In XPD 751 variant allele polymorphisms varied between populations. Only the CEU (0.33) population showed similarity to the Saudi population (0.4) (Table 4). OGG1 variant frequencies are higher in Chinese (0.5) and Japanese (0.523) populations and all the populations compared were significantly different from the Saudi population. OGG1 Ser326Cys has been reported to be associated with lung cancer risk in Chinese, Japanese, African and European populations (Duan et al., 2012). XRCC3, XPD and OGG1 polymorphism associations with diseases are yet to be studied in Saudi populations.

Establishing the baseline frequency of the various DNA repair alleles within a population may help to find out ethnicbased risk against environmental insults and susceptibility to carcinogenesis. In addition to their role in cancer risk, DNA repair polymorphisms may also influence a response to survival and/or treatment. Therefore, the polymorphisms in the genes involved in the DNA repair mechanism may play a role in pharmacogenetics by altering the repair capability as a result of cytotoxic or radiation therapy. Further studies on the phenotypic effects of these polymorphisms in random individuals of distinct ethnic origin based on life styles and environmental exposures will generate a clear picture, not only of the functional effects of the various genotypes, but also about the gene $X$ environment interactions.

In conclusion, our study may provide a preliminary basis for cancer risk assessments that are associated with polymorphisms among these DNA repair genes by performing genetic epidemiological studies in the central region population of Saudi Arabia. Furthermore, our results indicate a distinct molecular profile of polymorphisms for the DNA repair genes XRCC1, XRCC3, OGG1 and XPD loci for CRS compared to other populations.

\section{ACKNOWLEDGEMENTS}

The Authors extend their appreciation to the Deanship of Scientific Research at King Saud University for funding the work through the research group project No: RGP-VPP-081.

\section{REFERENCES}

ALSBEIH GA, EL-SEBAIE MM, AL-RAJHI NM, AL-HARBI NM, ALHADYAN KS, AL-BUHAIRI MH, MOFTAH BA, AL-SHABANAH MO, ABU-AMERO KK (2008) Association between XRCC1 G399A polymorphism and late complications to radiotherapy in Saudi head and neck cancer patients. J Egypt Natl Canc Inst 20(3):302-328.

ANDREW AS, NELSON HH, KELSEY KT, MOORE JH, MENG AC, CASELLA DP (2006) Concordance of multiple analytical approaches demonstrates a complex relationship between DNA repair gene SNPs, smoking and bladder cancer susceptibility. Carcinogenesis 27(5):1030-1037.

BENHAMOU S, SARASIN A (2002) ERCC2/XPD gene polymorphisms and cancer risk. Mutagenesis 17: 463-469.

BRENNEMAN MA, WEISS AE, NICKOLOFF JA, CHEN DJ (2000) XRCC3 is required for efficient repair of chromosome breaks by homologous recombination. Mutat Res 459: 89-97.

CALDECOTT KW (2003) XRCC1 and DNA strand break repair. DNA Repair (Amst) 2: 955-969.

CHARAMES GS, BAPAT B (2003) Genomic instability and cancer. Curr Mol Med 3: 589-596.

CHEN JZ, KADLUBAR FF (2003) A new clue to glaucoma pathogenesis. Am J Med 114: 697-698.

CUI X, BRENNEMAN M, MEYNE J, OSHIMURA M, GOODWIN EH, CHEN DJ (1999) The XRCC2 and XRCC3 repair genes are required for chromosome stability in mammalian cells. Mutat Res 434(2): 75-88.

CUSTODIO AC, ALMEIDA LO, PINTO GR, SANTOS MJ, ALMEIDA JR, CLARA CA (2012) Variation in DNA repair gene XRCC3 affects susceptibility to astrocytomas and glioblastomas. Genetics Mol Res 11(1): 332-339.

DUAN WH, ZHU ZY, LIU JG, DONG MS, CHEN JZ, LIU QD (2012) XRCC1 Arg399Gln gene polymorphism and hepatocellular carcinoma risk in the Chinese Han population: a meta-analysis. Asia Pac J Cancer Prev 13(8):3601-3604

DUAN WX, HUA RX, YI W, SHEN LJ, JIN ZX, ZHAO YH, et al. (2012) The Association between OGG1 Ser326Cys Polymorphism and Lung Cancer Susceptibility: A Meta-Analysis of 27 Studies. Plos One 7(4).

ELAHI A, ZHENG Z, PARK J, EYRING K, MCCAFFREY T, LAZARUS P (2002) The human OGG1 DNA repair enzyme and its association with orolaryngeal cancer risk. Carcinogenesis 23(7):1229-1234.

EL-HAZMI MA, AL-SWAILEM AR, WARSY AS, AL-SWAILEM AM, SULAIMANI R, AL-MESHARI AA (1995) Consanguinity among the Saudi Arabian population. Journal of Medical Genetics 32(8): 623-626.

FRIEDBERG EC, WALKER GC, SIEDE W (1995) DNA Repair and Mutagenesis. ASM Press, Washington (DC).

GANGWAR R, MANCHANDA PK, MITTAL RD (2009) Implications of XRCC1, XPD and APE1 gene polymorphism in north Indian population: A comparative approach in different ethnic groups worldwide. Genetica 136(1): 163-169.

GRIFFIN CS, SIMPSON PJ, WILSON CR, THACKER J (2000) Mammalian recombination-repair genes XRCC2 and XRCC3 promote correct chromosome segregation. Nat Cell Biol 2(10): 757-761.

HARITHY RN, GHAZZAWI WM (2011) Polymorphisms of the deoxyribonucleic acid (DNA) repair gene XRCC1 and risk of colon cancer in Saudi patients. Int J Med Med Sci 3(9): 282-288.

IANNUZZI MC, MALIARIK M, RYBICKI B (2002) Genetic polymorphisms in lung disease: bandwagon or breakthrough? Respir Res 3:15-22.

IMPROTA G, SGAMBATO A, BIANCHINO G, ZUPA A, GRIECO V, LA TORRE G, CITTADINI A (2008) Polymorphisms of the DNA repair genes XRCC1 and XRCC3 and risk of lung and colorectal cancer: a casecontrol study in a Southern Italian population. Anticancer Res 28(5B): 2941-2946.

KELSEY KT, PARK S, NELSON HH, KARAGAS MR (2004) A populationbased case-control study of the XRCC1 Arg399Gln polymorphism and susceptibility to bladder cancer. Cancer Epidem Biomar 13(8):1337-1341.

KERTAT K, ROSDAHL I, SUN XF, SYNNERSTAD I, ZHANG H (2008) The Gln/Gln genotype of XPD codon 751 as a genetic marker for melanoma risk and Lys/Gln as an important predictor for melanoma progression: A case control study in the Swedish population. Oncol Rep 20:179-183.

KOHNO T, KUNITOH H, TOYAMA K, YAMAMOTO S, KUCHIBA A, SAITO D, YANAGITANI N, ISHIHARA S, SAITO R, YOKOTA J (2006) Association of the OGG1-Ser326Cys polymorphism with lung adenocarcinoma risk. Cancer Sci 97:724-728.

KRUPA R, SLIWINSKI T, WISNIEWSKA-JAROSINSKA M, CHOJNACKI J, WASYLECKA M, DZIKI L, MORAWIEC J, BLASIAK J (2011) Polymorphisms in RAD51, XRCC2 and XRCC3 genes of the homologous 
recombination repair in colorectal cancer-a case control study. Mol Biol Reports 38(4): 2849-2854.

KUSCHEL B, AURANEN A, MCBRIDE S, NOVIK KL, ANTONIOU A, LIPSCOMBE JM, DAYhttp://hmg.oxfordjournals.org/ content/11/12/1399.short - aff-3 NE, EASTONhttp://hmg. oxfordjournals.org/content/11/12/1399.short - aff-2 DF, PONDERhttp: / / hmg.oxfordjournals.org/content/11/12/1399.short - aff-1 BAJ, PHAROAH PDP, DUNNING A (2002) Variants in DNA double-strand break repair genes and breast cancer susceptibility. Hum Mol Genet 11(12):1399-1407.

LIVAK KJ (1999) Allelic discrimination using fluorogenic probes and the 5' nuclease assay. Genet Anal: Biomol Engineer 14: 143-149.

LOPEZ-CIMA MF, GONZALEZ-ARRIAGA P, GARCIA-CASTRO L, PASCUAL T, MARRON MG, PUENTE XS, et al. (2007) Polymorphisms in XPC, XPD, XRCC1, and XRCC3 DNA repair genes and lung cancer risk in a population of northern Spain. BMC cancer 7:162.

LUNN RM, LANGLOIS RG, HSIEH LL, THOMPSON CL, BELL DA (1999) XRCC1 polymorphisms: Effects on aflatoxin B1-DNA adducts and glycophorin A variant frequency. Cancer Res 59: 2557-2561.

MAJUMDER M, SIKDAR N, GHOSH S, ROY B (2007) Polymorphisms at $\mathrm{XPD}$ and XRCC1 DNA repair loci and increased risk of oral leukoplakia and cancer among NAT2 slow acetylators. Int J Cancer 120: 2148-2156.

MAJUMDER M, SIKDAR N, PAUL RR, ROY B (2005) Increased risk of oral leukoplakia and cancer among mixed tobacco users carrying XRCC1 variant haplotypes and cancer among smokers carrying two risk genotypes: one on each of two loci, GSTM3 and XRCC1 (codon 280). Cancer Epidem Biomar 14: 2106-2112.

MATULLO G, GUARRERA S, CARTURAN S, PELUSO M, MALAVEILLE C, DAVICO L, PIAZZA A, VINEIS P (2001a) DNA repair gene polymorphisms, bulky DNA adducts in white blood cells and bladder cancer in a case-control study. Int J Cancer 92:562-567.

MATULLO G, PALLI D, PELUSO M, GUARRERA S, CARTURAN S, CELENTANO E, KROGH V, MUNNIA A, TUMINO R, POLIDORO $\mathrm{S}$, PIAZZA A, VINEIS P (2001b) XRCC1, XRCC3, XPD gene polymorphisms, smoking and (32)P-DNA adducts in a sample of healthy subjects. Carcinogenesis 22: 1437-1445.

MOULLAN N, COX DG, ANGELE S, ROMESTAING P, GERARD JP, HALL J (2003) Polymorphisms in the DNA repair gene XRCC1, breast cancer risk, and response to radiotherapy. Cancer Epidem Biomar 12(11): 1168-1174.

PRAMANIK S, DEVI S, CHOWDHARY S, SURENDRAN ST, KRISHNAMURTHI K, CHAKRABARTI T (2011) DNA repair gene polymorphisms at XRCC1, XRCC3, XPD, and OGG1 loci in Maharashtrian population of central India. Chemosphere 82: 941-946.

RATNASINGHE D, YAO SX, TANGREA JA, QIAO YL, ANDERSEN MR, BARRETT MJ, GIFFEN CA, EROZAN Y, TOCKMAN MS, TAYLOR PR (2001) Polymorphisms of the DNA repair gene XRCC1 and lung cancer risk. Cancer Epidem Biomar 10(2): 119-123.

SAMBROOK J, FRITSCH EF, MANIATIS T (1989) Molecular Cloning: a laboratory manual. 2nd ed. Cold Spring Harbor Laboratory: Cold Spring Harbor Laboratory Press. pp1659.

SAMSON M, SINGH SS, RAMA R, SRIDEVI V, RAJKUMAR T (2011) XPD Lys751Gln increases the risk of breast cancer. Oncol Lett 2:155-159.

SHINMURA K, YOKOTA J (2001) The OGG1 gene encodes a repair enzyme for oxidatively damaged DNA and is involved in human carcinogenesis. Antioxid Redox Signal 3: 597-609.

SKJELBRED CF, SAEBO M, WALLIN H, NEXO BA, HAGEN PC, LOTHE IM, AASE S, JOHNSON E, HANSTEEN IL, VOGEL U, KURE EH (2006) Polymorphisms of the XRCC1, XRCC3 and XPD genes and risk of colorectal adenoma and carcinoma, in a Norwegian cohort: A case control study. BMC Cancer 6: 67.

STURGIS EM, CASTILLO EJ, LI L, ZHENG R, EICHER SA, CLAYMAN GL, STROM SS, SPITZ MR, WEI Q (1999) Polymorphisms of DNA repair gene XRCC1 in squamous cell carcinoma of the head and neck. Carcinogenesis 20: 2125-2129.

VETTRISELVI V, VIJAYALAKSHMI K, SOLOMON PF, VENKATACHALAM $P$ (2007) XRCC1 and XPD gene polymorphisms in a south Indian population. Asian Pac J Cancer Prev 8(2): 283-286.

XUE H, LU Y, LIN B, CHEN J, TANG F (2012) The Effect of XPD/ERCC2 Polymorphisms on Gastric Cancer Risk among Different Ethnicities: A Systematic Review and Meta-Analysis. PLoS One 7(9).

YUAN L, CUI D, ZHAO EJ, JIA CZ, WANG LD, LU WQ (2011) XPD Lys751Gln polymorphism and esophageal cancer risk: a meta-analysis involving 2288 cases and 4096 controls. World J Gastroentero 17(18): 2343-2348.

ZHAN P, WANG Q, WEI SZ, WANG J, OIAN O, YU LK, SONG Y (2010) ERCC2/XPD Lys751Gln and Asp312Asn gene polymorphism and lung cancer risk: a meta-analysis involving 22 case-control studies. J Thorac Oncol 5(9): 1337-1345.

ZHANG ZY, XUAN Y, JIN XY, TIAN X, WU R (2013) Meta-analysis demonstrates association of XRCC1 genetic polymorphism Arg399Gln with esophageal cancer risk in the Chinese population. Genetics Mol Res 12(AOP). 
7 Parine BR 46-2.indd 168

28-06-13 $\quad 17: 59$ 